\title{
CARTOGRAFIA DA PAISAGEM E USO DE IMAGENS ORBITAIS NA INTERPRETAÇÃO GEOMORFOLÓGICA
}

\author{
Jhony Gonçalves Lima ${ }^{(a)}$, Felipe Henrique da Silva Andrade ${ }^{(b)}$ \\ (a)Universidade Federal do Piauí, Email: jhonygoncalvesdelima@gmail.com. \\ (b) Universidade Estadual do Piauí, Email: felipegeo@outlook.com.
}

\section{Eixo: GEOTECNOLOGIAS E MODELAGEM ESPACIAL EM GEOGRAFIA FÍSICA}

\begin{abstract}
Resumo/
A presente pesquisa tem como objetivo verificar a aplicabilidade de imagens orbitais nos estudos da paisagem destacando os aspectos geomorfológicos no município de Matões/MA. Para tanto se procedeu com revisão bibliográfica, de campo e pesquisa de gabinete para aquisição de imagens de satelite. Os resultados apontaram que a aplicação dos metodos computacionais, apresentou resultados satisfatórios, revelando que $47 \%$ do total da area de estudo possui declividade $<2 \%, 18 \%$ da area possui declividade entre $2-5 \%, 14 \%$ possui declividade entre $5-10 \%, 9 \%$ do total da área possui declividade entre $10-15 \%$ e $12 \%$ aprentou declividade entre $15-45 \%$, percebendo-se que as vertentes com $<2 \%$ predominam na area de estudo. Deste modo o emprego de imagens de satélite mostrou-se adequado para a identificação e caracterização de paisagens, permitindo a classificação da declividade na área em estudo.
\end{abstract}

Palavras chave:Paisagem. Declividade. Cartografia da Paisagem. Imagens orbitais.

\section{Introdução}

As atividades humanas sempre constituíram um meio de modificação da natureza. Nesse processo de interação o homem acabou ajudando na constituição de diversos tipos de paisagens, que possuem características, dinâmicas e valores próprios. $\mathrm{O}$ advento das imagens orbitais no estudo da paisagem, tem intensificado as discussões da sua aplicabilidade no âmbito cartográfico, sendo cada vez maior as aplicações destas imagens na cartografia de paisagens.

O uso de imagens de satélite de alta resolução espacial em muitas áreas, permite agilidade, qualidade e baixo custo nos estudos. Destacamos a importância do estudo da aplicação destas imagens na interpretação geomorfológica na busca de estabelecer possíveis interações e relações existentes entre as características do relevo de um determinado recorte espacial e as predominâncias ambientais e paisagísticas que o compõe.

Para representação de fenômenos geográficos a Cartografia de Paisagens dispõe de uma série de recursos que permitem tais representações. Em detrimento a disponibilidade e boa qualidade de dados temáticos e da alta resolução das imagens de satélite ou das fotografias aéreas disponíveis, em alguns casos não 
necessita sequer da pesquisa de campo. No entanto como aponta Cavalcanti (2014) para elaborar um mapeamento detalhado, é necessário seguir um conjunto de etapas e sub etapas que vão desde o planejamento da pesquisa de campo até a elaboração da carta.

Compreendendo o relevo como um componente dos sistemas ambientais e que, a partir do conhecimento de suas estruturas e dinâmicas atuais e passadas é possível elaborar análises dos ambientes terrestres em que todos os fatores ambientais clima, relevo, vegetação, solo, geologia sejam estudados de forma integrada. A presente pesquisa tem como objetivo verificar a aplicabilidade de imagens orbitais nos estudos da paisagem destacando os aspectos geomorfológicos no município de Matões/MA.

\section{Metodologia}

O desenvolvimento da pesquisa de abordagem quali-quantitativa, contou com os procedimentos de revisão bibliográfica, pesquisa de campo e fase de gabinete. Foram realizadas pesquisas de campo para observação, marcação de pontos com receptor GPS, registro fotográfico e preenchimento de planilhas de campo.

Para criar o mapa de declividade da região foram usadas imagens SRTM, disponibilizadas no site da NASA. O processsamento foi realizado no software ArcGis 10.1. O processamento foi iniciado com a identificação e orientação da declividade, usando um algoritmo que analisa os valores de elevação, ou seja, os valores da direção da inclinação. Em seguida foi calculada a porcentagem aproximada de cada classe de declividade, sendo que as classes foram definidas com base no Manual da EMBRAPA. E por fim calculou-se a área que cada classe ocupa.

\section{Resultados e discussão}

A pesquisa foi desenvolvida no municipio de Matões localizado no Estado do Maranhãoque possui uma área territorial de $2.107,403 \mathrm{Km}^{2}$, o município possui limites ao norte com Timon, ao sul com a cidade de Parnarama, ao leste com o rio Parnaíba e Teresina e ao oeste com Caxias (MARANHÃO, 2010).

No que diz respeito à declividade, para Guerra e Guerra (1997), esta corresponde a maior ou menor inclinação do relevo em relação ao plano horizontal, ou seja, divide-se a diferença de nível pela distância horizontal e multiplica-se o resultado obtido por 100. Assim, o estudo da declividade é importante para analisar, entre outros aspectos, as condições pedológicas do local para verificar a sua aptidão para usos agrícolas, assim como para identificar áreas de maior declividade sujeitas ao escoamento superficial. 


\section{OS DESAFIOS DA GEOGRAFIA FÍSICA NA FRONTEIRA DO CONHECIMENTO \\ Instituto de Geociências - Unicamp \\ Campinas - SP \\ 28 de Junho à 02 de Julho de 2017}

Após aquisição e análise da imagem de satellite da área à classificação e tratamento da mesma, foi possivel extrair informações espaciais relativas ao relevo da região. A tabela I apresenta a distribuição das classes de declividade identificadas no municipio.

Tabela I- Classificação das classes de declividade do municipio de Matões/MA. Fonte: Andrade e Lima, 2016.

\begin{tabular}{|c|c|c|}
\hline \multicolumn{3}{|c|}{ Município de Matões- MA } \\
\hline Classe & Área (km) & Porcentagem (\%) \\
\hline 1-Plano (0\%-2\%) & 990,29 & 47 \\
\hline $\begin{array}{c}\text { 2-Suavemente Ondulado } \\
(2 \%-5 \%)\end{array}$ & 374,26 & 18 \\
\hline $\begin{array}{c}\text { 3-Moderadamente Ondulado } \\
(5 \%-10 \%)\end{array}$ & 316,05 & 14 \\
\hline 4-Ondulado (10\%-15\%) & 183,63 & 09 \\
\hline $\begin{array}{c}\text { 5-Fortemente } \\
\text { Ondulado(15\%-45\%) }\end{array}$ & 243,84 & 12 \\
\hline
\end{tabular}

A partir desses dados elaborou-se o mapa de declividade da área de estudo com a espacilaização das classes dentro do municipio conforme mostra a figura 1.

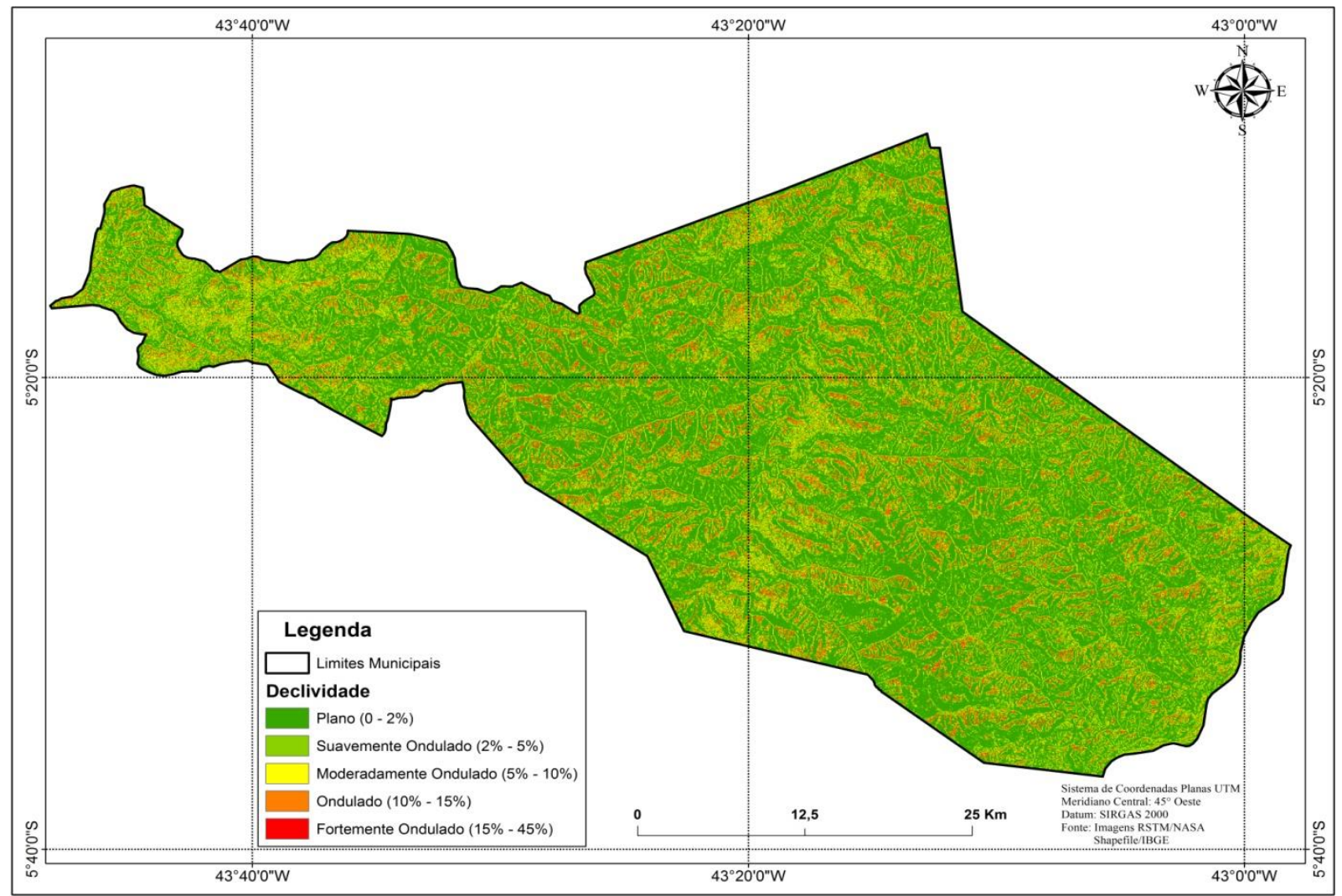

Figura 1- Mapa das classes de declividade do municpio de Matões/MA. Fonte: Andrade e Lima, 2016. 
A classe com variação de $0 \%$ a $2 \%$ possui relevo plano, sendo favorável a práticas agrícolas de culturas temporárias ou permanentes, não tendo impedimento a mecanização, desde que se utilize de um manejo adequado que leve em consideração as particularidades ambientais, principalmente, dos solos e do clima. Essa classe representa área de aproximadamente $990,29 \mathrm{~km}^{2}$, representando $47 \%$ da área de estudo.

A classe de 2 a $5 \%$ tem-se uma área de $374,26 \mathrm{~km}^{2}$, recobrem $18 \%$ da área do município. O relevo é suavemente ondulado, sendo recomendadas práticas de conservação do solo como o plantio em curva de nível. Já a classe de 5-10\% corresponde a uma área de $316,05 \mathrm{~km}^{2}$, aproximadamente $14 \%$ da área de estudo, o relevo é moderadamente ondulado, são áreas sujeitas a erosão, sofrendo restrições a mecanização e a práticas agrícolas, sendo recomendado a silvicultura (FIGURA 02) ou a conservação da vegetação nativa.
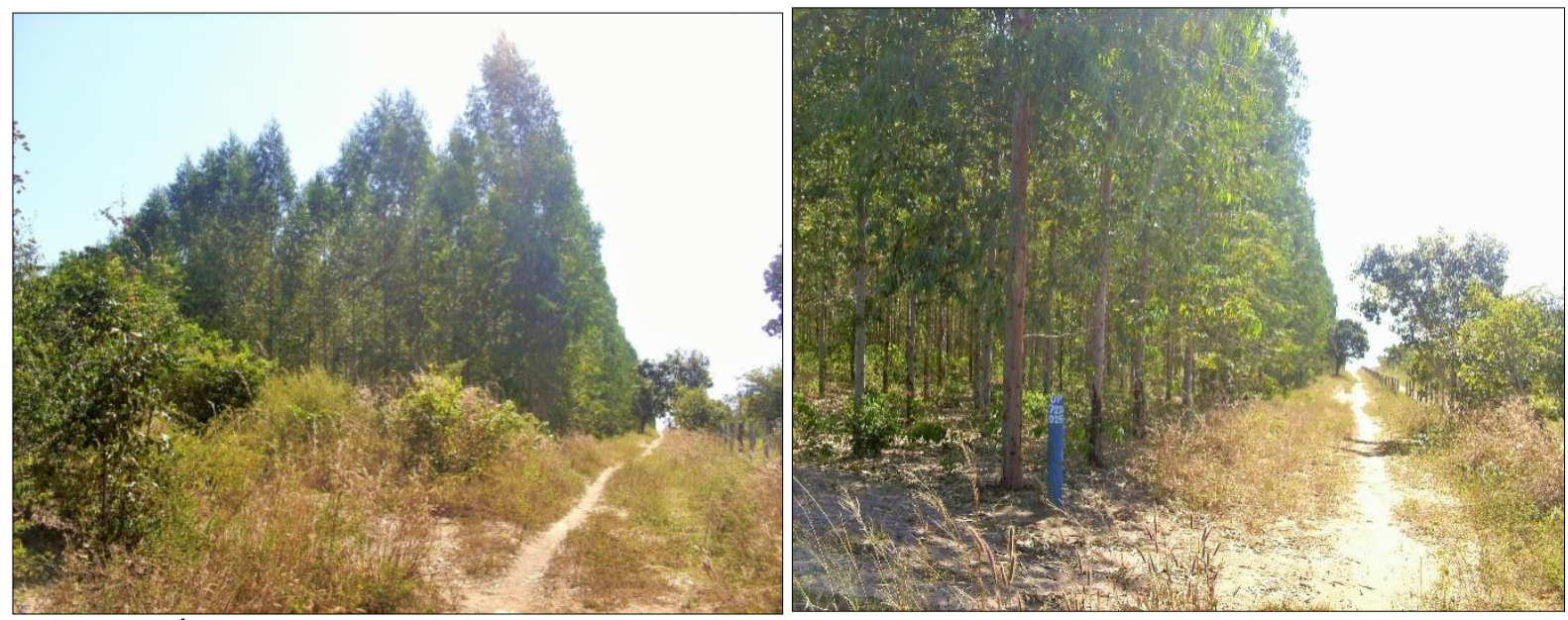

Figura 2- Área sob influência do plantio de eucalipto no município de Matões/MA. Fonte: Andrade e Lima, 2016.

Apesar do relevo plano e suavemente ondulado, esse solo vem sendo aproveitado para agricultura, destacando-se as culturas de milho, feijão, arroz e fruticultura (manga, caju e banana), além do extrativismo do coco babaçu, destaca-se nessas áreas que o cultivo do eucalipto que vem se expandido pela região (MARANHÃO, 2010). Para o cultivo as empresas empregam diversos produtos e técnicas para controle da erosão e correção desses solos através da aplicação de corretivos e adubos para atenuar os fatores limitantes ao desenvolvimento dessa monocultura, que vem apresentando bom desenvolvimento e adaptação no município de Matões.

A classe de $10 \%$ a $15 \%$ tem-se uma área de $183,63 \mathrm{Km}^{2}$, recobrindo $09 \%$ do município, o relevo é ondulado. E por fim a classe $15 \%$ a $45 \%$ possui relevo fortemente ondulado, representando área de 
aproximadamente $243,84 \mathrm{~km}^{2}$ que corresponde a $12 \%$ do total da área de estudo.Estas classes estão associadas às vertentes dos morros apresentando as áreas mais íngremes presentes no município.

\section{Considerações Finais}

Considerou-se que o estudo cartográfico de paisagens por meio de imagens de satélite, permite a compreensão não apenas da organização espacial dos fenômenos geográficos, mas também na interpretação geomorfológica possibilitando a identificação de interações e relações entre as características do relevo de um determinado local e as predominâncias ambientais e paisagísticas que o compõe.

No estudo realizado foi fundamental o tratamento dos dados em ambiente SIG, podendo-se identificar as classes de declividadepresenteno municipío de Matões/MA. Posteriormente,o uso dessas informações contribuiu para elaboração do mapa de declividade possibilitando a visualização da paisagem do município de maneira integrada por meio dos recursos da cartografia da paisagem.

\section{Bibliografia}

CAVALCANTI, L. C. S. Cartografia de paisagens: fundamentos. São Paulo: Oficina de textos, 2014.

GUERRA, A.T.; GUERRA, A.J.T. Novo dicionário Geológico-Geomorfológico. Rio de Janeiro: Bertrand Brasil, 1997. $652 \mathrm{p}$.

MARANHÃO. Plano Territorial de desenvolvimento Sustentável. Território Cocais. São Luís: COOSPAT, 2010. 